Journal Universitas Muhammadiyah Gresik Engineering, Social Science, and Health International Conference (UMGESHIC)

UMGCINMATIC : $1^{\text {st }}$ Rethinking Education during Covid-19 Era: Challange and Innovation

\title{
THE DEVELOPMENT OF TEAM-BASED INTERNAL SUPERVISION MODEL FOR PRIMARY SCHOOLS
}

\author{
Author \\ Hongmanee Prasansab ${ }^{1}$ \\ ${ }^{1}$ Loei Primary Educational Service Area Office 2, Wangsaphung district, Loei Provice 42130, \\ Thailand
}

\begin{abstract}
This research aimed to: 1) study the elements and develop a model for supervision by a team based in primary schools 2) study the result of model trial and 3) evaluate the model of Team -Based Internal Supervision Model. The research and development process was divided into 3 phases: Phase 1elements study, Phase 2 development model, and Phase 3 model evaluation. The first phase conducted by interviewing the outstanding schools and experts assessing. Phase 2 created a draft model and a manual, then tried out by a volunteer school. Phase 3 evaluated model by connoisseurship. The interview form, evaluation form, teaching observation form and connoisseurship record were applied for data collection. The quantitative data was analysed by percentage, mean, standard deviation while the qualitative data was analysed by content analysis. The results were as follows: 1 . The element and model of supervision by the team's base in primary schools could be divided into five main elements consisted of 1) principle 2) aim 3) process 4) output and 5) feedback. 2. The trial result of applying the supervision model found that teachers changed teaching behavior and paid more attention in teaching. Teachers tried to apply active learning in class activities that supported the students learning. In addition, the model also encouraged the team collaboration and effected the school internal supervision system. 3. Evaluation result found that the experts examined and corroborated the team-based internal supervision model in primary schools before applying the pattern suitability and utilization overall it is at the highest level
\end{abstract}

Keywords: Active learning, Internal Supervision, Team-Based 
UMGCINMATIC : $1^{\text {st }}$ Rethinking Education during Covid-19 Era: Challange and Innovation Volume 1 No 2

\section{INTRODUCTION}

Loei Primary Education Service Area Office 2 is an organization that plays an important role to promote and support the school to develop the administration and management of education. So that the learners have quality accordingly educational standards and international standards It is an agency that supervises, supports, advises, promotes and coordinating so that government teachers under the jurisdiction can perform their duties effectively along with Supervision and follow-up on the performance of educational institutions in order to have a positive effect on the development of the learning quality of the learners and manage educational activities in accordance with the needs and standards of school from the supervision and follow-up on the results of the internal supervision of the educational institutions under the past. It has not been as successful as it should be, that is, the implementation of internal supervision affects the quality of students. less than the specified target from the analysis of the reasons for many reasons have consistent information that the supervision operation was carried out in various forms, but the problem condition was that the operation was not complete every step and lack of continuity as follows 1) Preparation for supervision within educational institutions. Educational institutions lack personnel responsible for supervision or the supervision committee still lacks knowledge understanding and supervision skills lack of education, the need for supervision make the supervision planning was inconsistent with the needs of the supervisory teachers. Therefore, internal supervision not as effective as it should be because they are unable to solve problems or develop teachers as necessary or the needs of teachers also resulted in the lack of full cooperation in the educational institutions. 2) Operations supervision Most of the problems found that the supervision operation did not go according to plan. And the supervisors have workloads other than teaching supervision work. and teachers do not follow the rules or a present calendar of operations especially if the management does not pay attention to the development of the model proper supervision The opportunity for teachers to receive supervision in schools is therefore difficult. In addition, some educational institutions lack media and innovations in various forms of supervision. Who is knowledge that will be useful for internal supervision and 3 ) evaluation of supervision important problems in the supervision process within educational institutions and educational service area offices that are rarely the operation is supervision evaluation or supervision report most of the educational institutions. Educational institutions lack a person responsible for assessing supervision. Causing the evaluation to be unable to proceed. Seriously and continuously lack of development of tools for supervision as a result, the results cannot be taken. Take advantage for the development of supervision systems in educational institutions and to improve learning. Truly teaching serious and continuous and at present, the problem of supervision within the school still exists. There are several problems that prevent supervision from being as successful as it should be tteamwork is therefore one of the important strategies to encourage an organization or an educational institution to perform internal supervision effectively and achieve the objectives as an educational institution is an 
UMGCINMATIC : $1^{\text {st }}$ Rethinking Education during Covid-19 Era: Challange and Innovation Volume 1 No 2

educational unit which has changed quite a lot in all aspects, both in terms of management in the teaching and learning process on the characteristics of the learners.

\section{METHODS}

\subsection{Participants}

1) The participants for the first phase consisted of 3 schools that were outstanding schools . Those school were purposive sampling

2) The sample group in applying the model and a manual for using the model of internal supervision was a school in Loei Primary Educational Service Area Office 2 by purposive sampling

3) Experts Group consisted of 9 people who examined the draft model before trial and confirmed the correctness and appropriateness helpfulness and the possibility of the supervision model after trial by connoisseurship by purposive sampling .

\subsection{Measures}

The research tools used for data collection consisted of interview form, evaluation form, teaching observation form and connoisseurship record. All tools were inspected the content validity

and

reached

the

criteria

\subsection{Procedure and design}

The research and development methodology was used for this study divided into 3 phases: Phase 1 elements study, Phase 2 development model, and Phase 3 model evaluation. The first phase conducted by interviewing the outstanding schools and experts assessing. Phase 2 created a draft model and a manual, then tried out by a volunteer school. Phase 3 evaluated model by connoisseurship.

\subsection{Data analysis}

The statistics used in the data analysis were percentage, mean, standard deviation. and content analysis

The quantitative data was analysed by percentage, mean, standard deviation while the qualitative data was analysed by content analysis.

\section{DISCUSSION}

The development of a team-based internal supervision model in elementary schools from the summary The results of the research have important issues in discussion of the results as follows:

From the study of documents, concepts, theories and related research to bring information synthetic as an element in conducting research and from the assessment of the composition of qualified to create elements of a team-based internal supervision model in primary school. Which is a pattern or systematic process that represents the relationship of elements between the roles of supervisors and supervisors to cause development change 
and team work by promoting, supporting and raising awareness for the supervisors to see own potential accept what is and use that potential to the fullest therefore, the composition of the team-based internal supervision model in elementary school consists of 6 main components 20 sub-components, including the first component, the principle, has 4 subcomponents, consisting of 1) Aim for teachers to change their behavior in a better way 2) Change in teachers' behavior must come from changes within the teachers; 3 ) the changes in teaching behaviors of teachers need to be social support and 4) the person who is at the heart of teaching and learning development is the teacher. In With Hoy and Forsyth (1986) saying that 1 ) the person who is at the heart of teaching development is teachers 2) Teachers need freedom to develop teaching in their own way. 3) Change teacher teaching behaviors require social support, including the provision of physical stimulation. Wisdom and Professions 4) Fixed supervision patterns and using coercion will not cause success in teaching development 5) Teaching development is often successful in situations working as a professional partner not showing superiority and to encourage teachers to have seek knowledge and experiment The second component has three sub-components:

1) To enable teams to apply the principle of linking content to supervision process 2 ) To enable teams to use methods that are consistent with goals and 4) to enable teams to use coaching that is positively aligned with Beach and Reinhartz.(2000) said that educational supervision is an action to support and promote teachers to have goals. To develop long-term professional growth that will have the greatest impact on student development and such developments depend on a system based on positive thinking, trust and giving. Supporting teachers ' efforts to improve classroom teaching efficiency

2) Development of a team-based internal supervision model in primary schools has passed the internal supervision model using a team as a base and a manual from qualified suitability and utilization consistent with Stufflebeam and Shinkfield (2007) and Sirichai Kanchanawasee (2007) has mentioned the assessment standards that can be classified as 4 sections as follows: 1) Utilization Standards 2) Feasibility Standards 3 ) Appropriate Standards 4) Accuracy standard until obtaining a form of internal supervision using a team as a base in primary schools consists of 1 principle of internal supervision, 2 goals of internal supervision, 3 processes of internal supervision 4 success factors in internal supervision 5 outcomes 6 feedback User manual section Team-Based Internal Supervision in Elementary Schools Consists of Part 1 Introduction It consists of background, objectives, goals, and terminology definitions. Part 2 Forms of supervision. Internal, team-based in primary schools, consisting of 1 model component 2 development activities 3 model structure 4 content 5 media / learning resources 6 measurement and evaluation.

3) The results of using a team-based internal supervision model in secondary schools found that Team-based internal supervision model from the study of documents, concepts, theories and research the researcher's involvement has been assessed and verified by qualified persons. from fruitful school studies Best Practices in Internal Supervision and through the process of drafting by qualified persons developed to enhance the competency of the supervisory team to have knowledge and understanding have supervisory skills able to 
supervise learning management by using a team as a base as a result, teachers who receive supervision have to develop their potential in improved learning management, professional development and learning management behavior. from the evaluation of the supervisory team inside have knowledge and understanding of using the form of internal supervision. by evaluating from the test measure the knowledge of the supervisory team through an assessment and have the knowledge and understanding of the internal supervision process by using the team as a base, as measured by the score evaluation results before the training, found that the internal supervision team have knowledge and understanding of internal supervision. Team work and learning management process with a score of $45-55 \%$ and after the training to provide knowledge about internal supervision team work and learning management process with a score of $90-95 \%$, passing the assessment criteria, $75 \%$ of all show that the supervision team has knowledge and understanding about internal supervision and everyone learning management process. From the assessment of the learning management ability of the supervisory team internally, by self-assessment on the ability to manage learning in an active learning style, it was found that all supervisory team members have the highest level of learning management ability from the assessment. Teaching and learning behavior of supervised teachers by Team-Based Supervision and the method of observing the teaching behavior by the internal supervision team during the internal supervision operation. All teachers receiving supervision had a better order of developing teaching behaviors from teacher supervision by evaluating learning management using active learning

\section{CONCLUSION}

Based on the the study of documents, concepts, theories and related research to bring information synthetic as an element in conducting research and from the assessment of the composition of qualified to create elements of a team-based internal supervision model in primary school. Teaching and learning behave or of supervised teachers by TeamBased Supervision and the method of observing the teaching behavior by the internal supervision team during the internal supervision operation. All teachers receiving supervision had a better order of developing teaching behaviors from teacher supervision by evaluating learning management using active learning

\section{REFERENCES}

Abdulkareem, A.Y. (2011). Reforms in Higher Education in Nigeria and the Challenges of Globalization. Educational Thought, 7(2), 125-138, March.

Acheson, K.A. and M.D. Gall. (2003). Clinical Supervision and Teacher Development:

Pre-Service and In-Service Applications. 5th ed. New York: John Wiley and Sons.

Allan, A.G. (1984). Differentiated Supervision. 6th ed. Boston : Allyn and Bacon. BaffourAwuah.

(2011). Supervision of Instruction in Public Primary Schools in Ghana: Teachers' and Head Teachers' Perspectives. [online]. Available from : 
UMGCINMATIC : $1^{\text {st }}$ Rethinking Education during Covid-19 Era: Challange and Innovation Volume 1 No 2

https://core.ac.uk/download/pdf/11238964.pdf. [accessed 10 October 2017]. Bandura, A. (1986). Social Foundations Thought and Action: A Social Cognitive Theory. New Jersey : Prentice-Hall.

Bandura, A. (1997). Self-Efficacy: The Exercise of Control. New York : W.H. Freeman. Bardach, E. (1998). Getting Agencies to Work Together: The Practice and Theory of Managerial Craftsmanship. Washington DC. : Brookings Institution Press.

Bardo, J.W. and J.J. Hartman. (1982). Urban Sociology : A Systematic Introduction . New York : F.E. Peacock. Beach, D.M. and J. Reinhartz. (2000). Supervision Leadership : Focus on Instruction.

Boston : Allyn and Bacon.

Brown, W.B. and D.J. Moberg. (1980). Organizational Theory and Management : A Macro Approach.

New York : John Wiley and Sons.

Bulach, C. R., Boothe, D. and P. Michael. (1999). Teachers' Perceptions of the Extent to which Principals Practice Effective Supervisory Behaviors. Journal of School Research and Information, 17(4), 25-30.

Burton, W.H. and L.J. Bruckner (1995). Supervisor Instruction: A Developmental Process. New York: McGraw-Hill.

Chaudury, A. and M.B. Holbrook. (2001). The Chain of Effects from Brand Trust and Brand Affect to Brand Performance: the Role of Brand Loyalty. Journal of Marketing, 65(2), 81-93.

Collin, J.J. (2003). Modern and Postmodern Teacher Supervision and Evaluation : Perception of Secondary School Principals and Teachers. Dissertation Abstracts International, 64(1), 33-A, July.

Cook, C.W., Phillip, H. and E.C. Robert. (1997). Management and Organizational Behavior. 2nd ed. Boston : McGraw-Hill.

Counts, G.E., Shepard, I.S. and R.F. Farmer. (1998). Evolution and Supervision of Teacher in Missouri School. Missouri : EDRS.

Cruz, J.O. (2000). The Efficacy of the Social Work Model of Supervision for Education. [online]. Available from http://search.proquest.com/dissertations/docview/3046262167?accountid $=31098$. [accessed 10 October 2017].

Dubrin, A.J. and R.D. Ireland. (1993). Management and Organization. 2nd ed. Ohio : South Western Publishing.

Dyer, W.G. (1977). Team Building: Issues and Alternatives Reading. USA. : CA AddisonWesley Publisher.

Edgar, H.R. (1982). Team Building Citing Daniel Robery and Steven Altman Organization Development : Progress and Perspective. New York: McMillan Publishing. 